Original Research Paper

\title{
Production of Xylitol from Agricultural Waste by Enzymatic Methods
}

\author{
${ }^{1}$ Marie K. Walsh, ${ }^{2}$ Hussein Fadhil Khliaf and ${ }^{3}$ Khalida A. Shakir \\ ${ }^{I}$ Department of Nutrition, Dietetics and Food Sciences, Utah State University, 8700 Old Main Hill, Logan, UT, USA \\ ${ }^{2}$ General Company of Wheat Grain Processing, Wassit, Iraq \\ ${ }^{3}$ Department of Food Science, College of Agriculture, University of Baghdad, Baghdad, Iraq
}

Article history

Received: 05-02-2018

Revised 07-03-2018

Accepted: 20-03-2018

Corresponding Author:

Marie K. Walsh

Department of Nutrition,

Dietetics and Food Sciences,

Utah State University, 8700

Old Main Hill, Logan, UT,

84322-8700, USA

Tel: $1-435-797-2177$

Fax: 1-435-797-2177

Email: marie.walsh@usu.edu

\begin{abstract}
Enzyme catalyzed production of xylose from autoclaved and non-autoclaved wheat straw was conducted followed by bioconversion of xylose to xylitol using a Crude preparation of Xylose Reductase (CXR) from Candida guillermondii. Ground wheat straw (autoclaved and non autoclaved) was treated at 40 and $50^{\circ} \mathrm{C}$ for up to $9 \mathrm{~h}$ at $\mathrm{pH} 4.5$ with various concentrations of xylanase $(12.4$ to $37.2 \mathrm{U})$ and the reactions were assayed for reducing sugars. Hydrolysis of autoclaved wheat straw at $50^{\circ} \mathrm{C}$ for $3 \mathrm{~h}$ with $24.8 \mathrm{U}$ of xylanase at $\mathrm{pH} 4.5$ resulted in the highest yield of xylose (9.8\% of total xylose). Overall, the autoclave pretreatment resulted in a $22 \%$ higher yield of reducing sugars compared to the non pre-treated samples. The xylose hydrolysed wheat straw was adjusted to $\mathrm{pH} 7$ and the effects of temperature, $\mathrm{pH}$, time and $\mathrm{CXR}$ concentration were investigated to determine optimum conditions for xylitol production with NADPH. The optimal conditions for the synthesis of xylitol were $30^{\circ} \mathrm{C}$ at $\mathrm{pH} 7$ for $8 \mathrm{~h}$ with $7.92 \mathrm{U}$ of CXR and $10 \mathrm{mM}$ NADPH with $23.9 \mathrm{~g}$ xylose. This research shows that xylitol synthesis using only an enzymatic system is feasible.
\end{abstract}

Keywords: Wheat Straw, Xylanase, Xylose, Xylose Reductase, Xylitol

\section{Introduction}

Xylitol is a 5-carbon sugar classified as a sugar alcohol or polyol that is derived from plant xylan. It is used in the food and pharmaceutical industries as an alternative sweetener (Mohamad et al., 2015; Rafiqul and Sakinah, 2013). The benefits of xylitol over other sweeteners is that it does not react with amino acids in the Maillard reaction, has a sweetening power equivalent to sucrose with a lower caloric value $(2.4 \mathrm{cal} / \mathrm{g})$, is anticariogenic and undergoes insulin-independent metabolism (Rafiqul and Sakinah, 2013; Mohamad et al., 2015). Xylitol is currently used in oral hygiene products, chewing gum and confectionaries. Xylitol is found in small amounts in some fruits, vegetables, algae and mushrooms, but not at a level for commercial extraction.

Agricultural biomass consists of three fractions; cellulose $(35-55 \%)$, hemicellulose $(25-50 \%)$ and lignin $(12-35 \%)$ and the ratio of these fractions varies with plant species (Bajpai, 2016). The hemicellulose fraction is composed of xylan, galactoglucomannans and arabinoglucuronoxylan polymers. The monosaccharides of hemicellulose consist of xylose, glucose, arabinose, galactose and mannose and minor components such as glucuronic, acetic, ferulic and coumaric acids. Largescale, industrial production of xylitol from agricultural biomass (corn cobs, corn stover, rice straw, wheat straw and hardwood trees) includes acid hydrolysis followed by the chemical reduction of xylose (Mohamad et al., 2015 ). For this process, the recovery yield of xylitol is $50-60 \%$ of the xylan fraction or $8-15 \%$ of the initial raw material. The chemical conversion is energy intensive and includes extensive purification steps resulting in a high cost of the final xylitol (Rafiqul and Sakinah, 2013; Mohamad et al., 2015).

Research on the microbial production of xylitol is vast in the literature (reviewed in de Albuquerque et al., 2014). Microbes that can synthesize xylitol include yeasts, fungi and to a lesser extent bacteria. The most commonly used yeast for xylitol production are from the genus Candida, Pichia, Meyerozyma and Debaromyces. Xylitol is produced as a metabolic intermediate in organisms that utilize xylose. In microbes, xylose is reduced by Xylose Reductase (XR) (EC: 1.2.1.21). This enzyme requires $\mathrm{NAD}(\mathrm{P}) \mathrm{H}$ as a cofactor. The xylitol can be secreted or used in metabolism via dehydrogenation 
with xylitol dehydrogenase (XDH: EC. 1.1.1.9) to produce xylulose. Xylulose is then phosphorylated to xylose-5-phosphate that is further metabolized through the pentose phosphate pathway. Under low oxygen conditions, the accumulation/secretion of xylitol is favored rather than the metabolism (de Albuquerque et al., 2014; Rafiqul and Sakinah, 2013). The xylitol yields from the microbial fermentation can be in the range of $50-90 \%$ but suffers from limitations discussed below.

The general process for microbial xylitol production starts with an acid digest of agricultural biomass using a low acid amount $(2-5 \%)$ that easily degrades the hemicellulose rather than the cellulose fraction. The acid hydrolyzed biomass requires neutralization and removal of toxic compounds that are produced during hydrolysis since they are inhibitors of microbial growth. Toxic compounds include furan derivatives, aliphatic acids and phenolic compounds. Detoxification can include $\mathrm{pH}$ adjustment, solvent extraction, ion exchange, use of activated charcoal and evaporation, all of which are costly steps (Rafiqul and Sakinah, 2013; Mohamad et al., 2015). Additional limitations with the fermentation method include control of culture conditions (temperature, $\mathrm{pH}$, aeration), nutrients, water requirements and extensive purification from the fermentation media, all of which make the chemical process more economical.

Less research has been conducted on the enzymatic synthesis of xylitol. Enzymatic saccharification of lignocellulose for the production of bioethanol (Madadi et al., 2017), for use in the pulp and paper industry (Walia et al., 2017) or for production of xylooligosaccharids (Akpinar et al., 2009; Yoon et al., 2006; Driss et al., 2014; Wan Azelee and Jahim, 2016) has been investigated. The enzymatic hydrolysis of xylan can be done with an endo-1-4-beta-xylanase (EC 3.2.1.8) and a beta-xylosidase (EC 3.2.1.3). The endo-xylanase cleaves the xylan internally while the beta-xylosidase cleaves the terminal monosaccharide. The enzymatic method of hemicellulose saccharification is specific for xylose and done under mild $\mathrm{pH}$ and temperature conditions that generally does not result in the production of microbial inhibitors, but has been shown to be not as efficient as acid digestion (Liavoga et al., 2007). Generally, the agricultural biomass will need a pre-treatment such as high temperature and pressure or the use of an alkali extraction to render the hemicellulose fraction more accessible to enzymatic attack (Liavoga et al., 2007; Yoon et al., 2006; Driss et al., 2014; Wan Azelee and Jahim, 2016; Akpinar et al., 2009).

Most of the research on the enzymatic production of xylitol has focused on the use of soluble XR (crude extracts purified from indigenous microorganisms or recombinantly produced). The limitation to the use of XR for xylitol is the expense of the cofactor. Rafiqul et al. (2015) showed that a yield of $71 \%$ xylitol can be reached with a crude XR extract from Candida tropicalis. Since xylose reduction is dependent of the $\mathrm{NAD}(\mathrm{P}) \mathrm{H}$ concentration, studies have investigated the regeneration of the cofactor in dual enzyme systems. Branco et al. (2011) showed a stoichiometric xylose/xylitol conversion with the use of glucose dehydrogenase and glucose in the reaction to regenerate the NADPH. Other researchers have coupled xylose reduction with the dehydrogenase activity of glycerol dehydrogenase (Zhang et al., 2011) or formate dehydrogenase (Sung-Hwan et al., 2003; Neuhauser et al., 1998 ) for the regeneration of $\mathrm{NAD}(\mathrm{P}) \mathrm{H}$.

This research investigated the synthesis of xylitol from wheat straw using only an enzymatic system. Wheat straw was hydrolyzed with a xylanase from Trichoderma viride for the production of xylose and a crude XR extract from Candida guillermondii was used for the conversion of xylose to xylitol. This is the first publication to explore the synthesis of xylitol from agricultural biomass using exclusively enzymatic reactions.

\section{Materials and Methods}

\section{Materials}

Wheat straw was obtained from a local farm in Wassit Governorate in Iraq. The straw was air dried, milled and screened to capture particles of sizes less than $0.5 \mathrm{~mm}$ and straw particles were washed with distilled water. All other chemicals were analytical grade and were obtained from Sigma-Aldrich, except the ones mentioned in the text.

\section{Determination of Monosaccharaides in Wheat Straw}

Ground wheat straw (20-40 mesh) was hydrolyzed to monosaccharides according to Liavoga et al. (2007). Wheat straw, $(1.0 \mathrm{~g})$ was mixed with $72 \%$ sulfuric acid $(10 \mathrm{~mL})$ and the mixture held at $30^{\circ} \mathrm{C}$ for $1 \mathrm{~h}$ with stirring. The concentration of acid in the mixture was adjusted to $4.0 \%$ by adding it to water $(170 \mathrm{~mL})$ and the mixture heated at boiling reflux for $2 \mathrm{~h}$. An aliquot (20 $\mu \mathrm{L}$ ) of the hydrolysate was diluted to $10 \mathrm{~mL}$ with water and the monosaccharides in the liquid fraction were analyzed by HPLC. The HPLC system consisted of a Jasco AS-950-10 injector, a Jasco PU-980 pump, a Shimadzu CTO-6A heating oven and a Shimadzu ERC$7515 \mathrm{~A}$ refractive index detector. The HPLC conditions were according to Tamburini et al. (2015). An Aminex HPX-87P column (BioRad) was used with $0.02 \mathrm{M} \mathrm{H}_{2} \mathrm{SO}_{4}$ as the solvent at a flow rate of 0.6 $\mathrm{ml} / \mathrm{min}$ at $45^{\circ} \mathrm{C}$. The standards used were glucose, xylose, xylitol and furfural.

\section{Xylose Standard Curve}

Seven different concentrations $(0,0.2,0.4,0.6,0.8$, 1.0 and $1.2 \mathrm{mg} / \mathrm{mL}$ ) of xylose (D- $(+)-$ xylose, $>99 \%$ pure) were prepared in distilled water. 3,5-Dinitro-2- 
hydroxybenzoic acid, $10.6 \mathrm{~g}$ (DNS), was dissolved in $1416 \mathrm{~mL}$ of distilled water containing $19.5 \mathrm{~g}$ sodium hydroxide and heated to $80^{\circ} \mathrm{C}$ until solution was clear. Then melted phenol, $7.5 \mathrm{~mL}$ and sodium bisulphate $8.3 \mathrm{~g}$ was added to the cooled solution. The DNS solution was then filtered through a coarse sintered glass filter and stored at $25^{\circ} \mathrm{C}$ in an amber colored bottle to prevent photo oxidation and used to determine reducing sugars in samples. Two $\mathrm{ml}$ of each concentration of xylose in triplicate was added to $2 \mathrm{~mL}$ of DNS solution. The samples were placed in boiling water for $5 \mathrm{~min}$ and cooled. The absorbance at $540 \mathrm{~nm}$ was measured and a standard curve was plotted (Miller, 1959). The average absorbance values for $0,0.2,0.4,0.6,0.8,1.0$ and 1.2 $\mathrm{mg} / \mathrm{mL}$ xylose were $0,0.33,0.52,0.69,0.93,1.06$ and 1.28. The standard curve was A540 nm $=0.9443 \mathrm{x}+$ 0.1407 with an $\mathrm{R}^{2}$ of 0.944 ( $\mathrm{x}=\mathrm{mg} / \mathrm{ml}$ reducing sugars) and was used to determine the conversion of hemicellulose into reducing sugars as described in Akpinar et al. (2009).

\section{Enzymatic Hydrolysis of Wheat Straw}

Ground wheat straw (10 g in $100 \mathrm{~mL}$ water) was autoclaved at $121^{\circ} \mathrm{C}$ for $20 \mathrm{~min}$ before hydrolysis by xylanase EC 3.2.1.8 (from Trichoderma viride, lyophilized powder reconstituted to $24.8 \mathrm{U} / \mathrm{mL}$ in 50 $\mathrm{mM}$ phosphate buffer, $\mathrm{pH}$ 6, Sigma-Aldrich) with the control being non autoclaved wheat straw. Enzymatic hydrolysis was carried out in total of $100 \mathrm{~mL}$ reaction volumes with $10 \mathrm{~g}$ of wheat straw in $50 \mathrm{mM}$ sodium acetate buffer, $\mathrm{pH} 4.5$ with $12.4,24.8$ and $37.2 \mathrm{U}$ of xylanase. All treatments were incubated in an orbital shaker at either 40 or $50^{\circ} \mathrm{C}$ for 1,2 or 3 hrs with constant agitation at $200 \mathrm{rpm}$. All samples were incubated for a total of $12 \mathrm{~h}$ and analyzed at that time point. Aliquots, 5 $\mathrm{mL}$, of the hydrolysates were withdrawn from samples, centrifuged and filtered using Whatman \#4 filter paper to remove the unhydrolyzed cellulose and lignin. The hydrolysis was stopped in $1 \mathrm{~mL}$ samples from the hydrolysate suspensions with the addition of $1.5 \mathrm{~mL}$ DNS solution, then placed in boiling water for $5 \mathrm{~min}$. The samples were cooled to room temperature, centrifuged at $13,000 \times \mathrm{g}$ for $5 \mathrm{~min}$ and the absorbance of the supernatants were measured at $540 \mathrm{~nm}$. Absorbance values were compared to the xylose standard curve to determine the reducing sugar yield. The efficiency of the hydrolysis reactions for the optimization of the hydrolysis conditions was based on quantification of reducing sugars as described by Akpinar et al. (2009). The xylose concentration in the treatment that yielded the highest amount of reducing sugars was determined via HPLC as described above and used in the enzymatic synthesis of xylitol as described below. All parameter screenings were carried out in triplicates and the standard deviations are shown in error bars.

\section{Enzymatic Synthesis of Xylitol}

The enzymatic conversion of xylose, prepared from enzymatic hydrolysis described above, to xylitol was conducted with a crude cell lysate from Candida guillermondii FTI 20037. Cell cultivation was done on plates and in media as described by Rafiqul et al. (2105). Cells were grown on yeast-extract peptone dextrose (YPD) agar plates at $30^{\circ} \mathrm{C}$ for $30 \mathrm{~h}$ and maintained at $4^{\circ} \mathrm{C}$. Growth medium was composed of $5 \mathrm{~g} / \mathrm{L}$ yeast extract, $5 \mathrm{~g} / \mathrm{L}$ peptone, $20 \mathrm{~g} / \mathrm{L}$ xylose, $3 \mathrm{~g} / \mathrm{L} \mathrm{K}_{2} \mathrm{HPO}_{4}$ and $1 \mathrm{~g} / \mathrm{L} \mathrm{MgSO}_{4}$ and cells were grown at $30^{\circ} \mathrm{C}$ at $150 \mathrm{rpm}$ for 18-24 h (Rafiqul et al., 2105). Cells were harvested by centrifugation at $6000 \mathrm{rpm}$ and washed in phosphate buffer (50 mM, pH 7.2) and re-centrifuged. The cell pellet was disrupted using a sonicator (SONICS, USA) at $4{ }^{\circ} \mathrm{C}$ for $20 \mathrm{~min}$. Cell homogenates were centrifuged at 10,000 rpm for $15 \mathrm{~min}$ at $4^{\circ} \mathrm{C}$ and the supernatant was used as Crude Xylose Reductase (CXR) extract.

The XR activity in the crude extract was determined by incubating $100 \mu \mathrm{L}$ of $5 \mathrm{mM}$ xylose, $10 \mathrm{mM}$ NADPH, $250 \mu \mathrm{L}$ of enzyme extract and $600 \mu \mathrm{L}$ of $50 \mathrm{mM}$ phosphate buffer ( $\mathrm{pH} 7)$. The reaction was carried out in $1 \mathrm{~mL}$ spectrophotometer cell at room temperature and the CXR activity was determined spectrophotometrically at $340 \mathrm{~nm}$ at room temperature according to Cortez et al. (2006). One unit of XR was defined as the amount of enzyme required to produce one $\mu \mathrm{mol}$ of NADP per minute, which is equivalent to one micro mole of xylitol. The CXR extract was found to have $13.2 \mathrm{U} / \mathrm{ml}$.

The enzymatic production of xylitol was carried out by incubation of CXR with wheat straw enzymatic hydrolysate (23.59 mg xylose) in Erlenmeyer flasks (25 $\mathrm{mL}$ ) containing $0.1 \mathrm{M}$ phosphate buffer ( $\mathrm{pH} 7.0), \mathrm{CXR}$ and NADPH. The $\mathrm{pH}$ was adjusted with $\mathrm{NaOH}$ to ensure the $\mathrm{pH}$ of the hydrolysate was 7 . The initial conditions were $30^{\circ} \mathrm{C}, \mathrm{pH} 7,10 \mathrm{mM}$ NADPH and $7.92 \mathrm{U}$ of CXR. Boiled CXR was used as a control. Following mixing, a $100 \mu \mathrm{L}$ volume was withdrawn to use as a zero time reaction, boiled and then stored until analysis. The remainder of the reaction mixture was incubated at different experimental conditions. The following treatment conditions were applied: time range $(2,4,6,8,10$ and $12 \mathrm{~h}$ ), incubation temperature $\left(25,30,35\right.$ and $\left.40^{\circ} \mathrm{C}\right)$, concentration of CXR (2.64 U, 5.28 U, 7.92 U and 10.56 $\mathrm{U})$ and $\mathrm{pH}$ values of 6,7 and 8 using $0.1 \mathrm{M}$ phosphate buffer. For the effects of temperature, samples were analyzed at pH 7 with $7.92 \mathrm{U}$ of CXR after $8 \mathrm{hrs}$. For the effects of $\mathrm{pH}$, samples were analyzed after $8 \mathrm{hrs}$ with $7.92 \mathrm{U}$ of $\mathrm{CXR}$ at $30^{\circ} \mathrm{C}$. For the effects of time, samples were analyzed at $\mathrm{pH} 7$ at $30^{\circ} \mathrm{C}$ with $7.92 \mathrm{U}$ of CXR. For the effects of enzyme concentration, samples were analyzed at $\mathrm{pH} 7$ at $30^{\circ} \mathrm{C}$ after $8 \mathrm{~h}$.

The reactions were stopped by heating the reaction mixture in boiling water at $100^{\circ} \mathrm{C}$ for $5 \mathrm{~min}$. The supernatant was stored at $-20^{\circ} \mathrm{C}$ and reactions monitored 
for reducing sugar concentration using DNS to confirm xylose conversion to xylitol (xylitol is not a reducing sugar) and samples were further analyzed for xylitol via HPLC as described earlier.

\section{Statistical Analyses}

All experiments were replicated three times and the data were statistically analyzed using analysis of variance (ANOVA) by GENSTAT computer software package. Differences between treatment averages were compared using Least Significant Difference (LSD) $\leq$ 0.05 probability level (Steel et al., 1997).

\section{Results and Discussion}

\section{Acid Hydrolysis of Wheat Straw}

The sugar content of the wheat straw as a result of acid hydrolysis is shown in Table 1 . The primary sugar present at $41.42 \%$ (dry weight) is glucose, derived from the breakdown of cellulose. Xylose is present at a concentration of $24.13 \%$ (dry weight), which corresponds to $241.3 \mathrm{mg}$ xylose $/ \mathrm{g}$ wheat straw. The remainder of the dry weight, $34.45 \%$, is presumably from lignin and other monosaccharides found in wheat straw. Liavoga et al. (2007) found that glucose and xylose comprised over three-fourths of the sugars in acid hydrolyzed wheat straw with minor amounts of arabinose $(2.7 \%)$ and galactose $(0.9 \%)$. Others (Harper and Lynch, 1981; Jacobs, 1999) found that the combined levels of arabinose, galactose and mannose in acid hydrolyzed wheat straw was between 3.6 and $4.2 \%$. The sugar content of wheat straw from this study shown in Table 1 is comparable to that previously reported.

\section{Enzymatic Hydrolysis of Wheat Straw}

Enzymatic hydrolysis of autoclaved and non autoclaved wheat straw was conducted using xylanase at different concentrations at incubation temperatures of 40 and $50^{\circ} \mathrm{C}$ at times from 1 to $9 \mathrm{~h}$ (Tables 2 and 3). In Tables 2 and 3, the mean reducing sugar concentrations as a result of xylanase (XR) hydrolysis are given and means with different letter superscripts between rows and columns are statistically different. With autoclaved wheat straw, the highest reducing sugar yields ( $9.8 \%$ of total xylose) were obtained using 24.8 $\mathrm{U}$ of xylanase at $40^{\circ} \mathrm{C}$ for 2 and $3 \mathrm{~h}$ while the lowest yield (5.9\% of total xylose) was obtained with $12.4 \mathrm{U}$ of xylanase at $50^{\circ} \mathrm{C}$ for $1 \mathrm{~h}$. In general, there was an increase in reducing sugar production with an increase in time, with $2 \mathrm{~h}$ showing the highest yield at $40^{\circ} \mathrm{C}$ and 3 $\mathrm{h}$ showing the highest yield at $50^{\circ} \mathrm{C}$.

Table 1: Sugar content of wheat straw as compared to literature values

\begin{tabular}{lll}
\hline & \% Dry Weight & \\
\cline { 2 - 3 } Study & Glucose & Xylose \\
\hline Current & 41.42 & 24.13 \\
Akpinar et al. (2009) & 39.50 & 20.60 \\
Liavoga et al. (2007) & 41.70 & 22.00 \\
Jacobs (1999) & 38.30 & 22.40 \\
Harper and Lynch (1981) & 36.40 & 23.40 \\
\hline
\end{tabular}

Table 2: Enzymatic hydrolysis of autoclaved wheat straw with xylanase (XY) for the production of reducing sugars at different concentrations of xylanase and at different incubation times and temperatures

\begin{tabular}{|c|c|c|c|c|}
\hline \multirow[b]{2}{*}{ Temp (C) } & \multirow[b]{2}{*}{$\begin{array}{l}\text { Incubation } \\
\text { time (hr) }\end{array}$} & \multicolumn{3}{|c|}{ Reducing Sugar Concentration (mg/g wheat straw) } \\
\hline & & (XY 12.4 U) & (XY $24.8 \mathrm{U})$ & (XY $37.2 \mathrm{U})$ \\
\hline$\overline{40}$ & 1 & $163.6^{\mathrm{a}}$ & $184.6^{\mathrm{e}}$ & $218.5^{1}$ \\
\hline 40 & 2 & $201.1^{b}$ & $235.9^{g}$ & $231.9^{\mathrm{g}}$ \\
\hline 40 & 3 & $197.5^{\mathrm{c}}$ & $232.4^{\mathrm{g}}$ & $231.6^{\mathrm{g}}$ \\
\hline 50 & 1 & $142.5^{\mathrm{d}}$ & $165.0^{\mathrm{a}}$ & $174.5^{\mathrm{k}}$ \\
\hline 50 & 2 & $186.2^{\mathrm{e}}$ & $195.7^{\mathrm{c}}$ & $205.6^{1}$ \\
\hline 50 & 3 & $213.8^{\mathrm{f}}$ & $220.7^{\mathrm{h}}$ & $220.5^{h}$ \\
\hline
\end{tabular}

Means followed by different letters between rows and columns are significantly different at $\mathrm{p}<0.05$

Total xylose in wheat straw is $241.3 \mathrm{mg} / \mathrm{g}$ wheat straw from Table 2

$\mathrm{XY}$ is xylanase and followed by the units used

Table 3: Enzymatic hydrolysis of non-autoclaved wheat straw with xylanase (XY) for the production of reducing sugars at different concentrations of xylanase and at different incubation times and temperatures

\begin{tabular}{|c|c|c|c|c|}
\hline \multirow[b]{2}{*}{ Temp (C) } & \multirow[b]{2}{*}{$\begin{array}{l}\text { Incubation } \\
\text { time (hr) }\end{array}$} & \multicolumn{3}{|c|}{ Reducing Sugar Concentration (mg/g wheat straw) } \\
\hline & & XY $12.4 \mathrm{U}$ & XY $24.8 \mathrm{U}$ & $\mathrm{XY} 37.2 \mathrm{U}$ \\
\hline 40 & 3 & $105.6^{\mathrm{a}}$ & $128.6^{\mathrm{d}}$ & $154.5^{1}$ \\
\hline 40 & 6 & $48.1^{\mathrm{b}}$ & $82.3^{\mathrm{f}}$ & $183.6^{\mathrm{f}}$ \\
\hline 40 & 9 & $39.5^{\mathrm{c}}$ & $183.4^{\mathrm{f}}$ & $184.4^{\mathrm{f}}$ \\
\hline 50 & 3 & $107.5^{\mathrm{a}}$ & $108.7^{\mathrm{a}}$ & $113.3^{\mathrm{j}}$ \\
\hline 50 & 6 & $126.8^{\mathrm{d}}$ & $133.7^{\mathrm{g}}$ & $145.2^{\mathrm{b}}$ \\
\hline 50 & 9 & $157.8^{\mathrm{e}}$ & $168.7^{\mathrm{h}}$ & $161.5^{\mathrm{k}}$ \\
\hline
\end{tabular}

Means followed by different letters between rows and columns are significantly different at $\mathrm{p}<0.05$

Total xylose in wheat straw is $241.3 \mathrm{mg} / \mathrm{g}$ wheat straw from Table 2

$\mathrm{XY}$ is xylanase and followed by the units used 
Samples were incubation for an additional $9 \mathrm{~h}$ and the reducing sugar concentration did not increase beyond the values obtained at 2 or $3 \mathrm{~h}$, therefore the hydrolysis time was not a limiting factor. With respect to enzyme concentration at $40^{\circ} \mathrm{C}$, there was in increase in reducing sugar production between 12.4 and $24.8 \mathrm{U}$ of xylanase, but there was no significant increase in reducing sugar production using $37.2 \mathrm{U}$ of xylanase at 2 and $3 \mathrm{~h}$. Therefore the amount of xylanase added was not a limiting factor. Overall, the reducing sugar yield was lower at $50^{\circ} \mathrm{C}$ compared to $40^{\circ} \mathrm{C}$ at all times and xylanase concentrations used.

With non-autoclaved wheat straw (Table 2), overall there was a lower yield of reducing sugar produced at each treatment tested compared to autoclaved wheat straw. The highest reducing sugar yield $(7.6 \%$ of total xylose) was produced using 24.8 and $37.2 \mathrm{U}$ of xylanase at $40^{\circ} \mathrm{C}$ at 6 and $9 \mathrm{~h}$. The lowest yields $(4.4 \%$ of total xylose) were observed at $3 \mathrm{~h}$ using 12.4 and $24 \mathrm{U}$ of xylanase at both 40 and $50^{\circ} \mathrm{C}$. With respect to enzyme concentration, as seen with autoclaved wheat straw, there was no increase in reducing sugar yield when the xylanase concentration was increased from 24.8 to 37.2 $\mathrm{U}$ at $40^{\circ} \mathrm{C}$. With respect to time, there was a general increase in reducing sugar yield with an increase in time. And as shown with autoclaved wheat straw, the reducing sugar yields were higher at 40 compared to $50^{\circ} \mathrm{C}$.

For the enzymatic production of xylose, agricultural biomass generally undergoes a pre-treatment to alter the lingocellulose structure to make it more accessible to the xylanase enzyme. Common pre-treatments include an alkali extraction (Wan Azelee and Jahim, 2016; Akpinar et al., 2009), or autohydrolysis at 160$260^{\circ} \mathrm{C}$ in water (Liavoga et al., 2007). Liavoga et al. (2007) pretreated wheat straw by heating a $10 \%$ solution (wt/vol) up to $200^{\circ} \mathrm{C}$ (hydrothermal treatment) before acid or xylanase treatment. They found that the xylanase treatment resulted in between $8-16 \%$ of the sugars in wheat straw released in samples that had undergone pretreatment (corresponding to 36 to $72 \%$ of the total xylose concentration) and was dependent on the commercial xylanase used. This was 16 times higher than for wheat straw that did not undergo a pre-treatment hydrolyzed with the same xylanases. Dilute acid hydrolysis can also be used to directly hydrolyze hemicellose to sugars. In the same study by Liavoga et al. (2007), a dilute acid hydrolysis resulted in up to $19 \%$ of xylose released in wheat straw (corresponding to $86 \%$ of the total xylose concentration). Mild acid and hydrothermal treatments generally disrupt the hemicellulosic sugars, while the crystalline cellulose remains intake. Both processes did result in the presence of minor amounts of other monosaccharides including arabinose, glucose and galactose (Liavoga et al., 2007). According to Liavoga et al. (2007) the enzymatic method is preferred over the acid processes since it is mild and not contaminated with mineral acid, thus allowing bioconversion of xylose to xylitol and potentially having cellulose as a substrate for ethanol production or ruminant feed.

Our pre-treatment consisted of autoclaving the ground wheat straw which is similar to the hydrothermal treatment used by Liavoga et al. (2007). In this study, based on the maximum yields obtained in Table 1 compared to Table 2 , we see a $22 \%$ increase in reducing sugar concentration using a wet autoclave pre-treatment. The highest yield of reducing sugar production was $9.8 \%$ of the xylose in autoclaved wheat straw, which is within the range of Liavoga et al. (2007), but on the lower end. This sample was analyzed by HPLC and found to contain 92\% xylose with the remainder mainly xylooligosasccharides and was used for xylitol synthesis.

The xylanase used here has a stated optimum temperature range from $40^{\circ} \mathrm{C}$ to $50^{\circ} \mathrm{C}$ at $\mathrm{pH} 4.5$ (SigmaAldrich product sheet). Gibson and McCleary (1987) showed that the xylanase from Trichoderma viride had an optimal activity at $\mathrm{pH} 4.5$ and was stable at a $\mathrm{pH}$ range of 3.4 to 7.9 and at temperatures between $30^{\circ} \mathrm{C}$ and below $55^{\circ} \mathrm{C}$. In this study, we did observe a low xylose yield at $50^{\circ} \mathrm{C}$ compared to $40^{\circ} \mathrm{C}$ which may have been from enzyme inactivation or end product inhibition (Akpinar et al., 2009). Enzymatic reactions at high temperatures $\left(>40^{\circ} \mathrm{C}\right)$ often result in higher yields due to better solubility of reactants and a lower viscosity. Therefore, a xylanase derived from a thermostable organism (e.g., Thermomyces lanuginosus or Geobacillus) would be preferable to the one used here if high temperatures are beneficial (Bhalla et al., 2015). Additionally, the use of higher enzyme concentrations did not result in additional hydrolysis of xylan which was also reported by Akpinar et al. (2009).

\section{Enzymatic Synthesis of Xylitol}

The synthesis of xylitol is dependent on the reaction temperature, $\mathrm{pH}$, time and enzyme concentration (Rafiqul et al., 2015). Figure 1 shows the enzymatic synthesis of xylitol using the CXR from Candida guillermondii as influenced by temperature, $\mathrm{pH}$, time and enzyme concentration. Within each graph in Fig. 1, the values with no common letter are statistically different. For each reaction, the amount of NADPH used was $10 \mathrm{mM}$ which was in excess of the amount of needed to reduce the amount of xylose in the reactions $(23.2 \mathrm{~g}$ xylose). With respect to temperature (Fig. 1A), the highest xylitol yield $(85.34 \%)$ was observed at $30^{\circ} \mathrm{C}$, although this was not statistically different than the yield obtained at 35 and $40^{\circ} \mathrm{C}$. The highest xylitol yield was obtained at $\mathrm{pH} 7$ $(82.22 \%)$, although this was not statistically differentthan the yields obtained at $\mathrm{pH}$ values of 6 and 8 (Fig. 1B). 


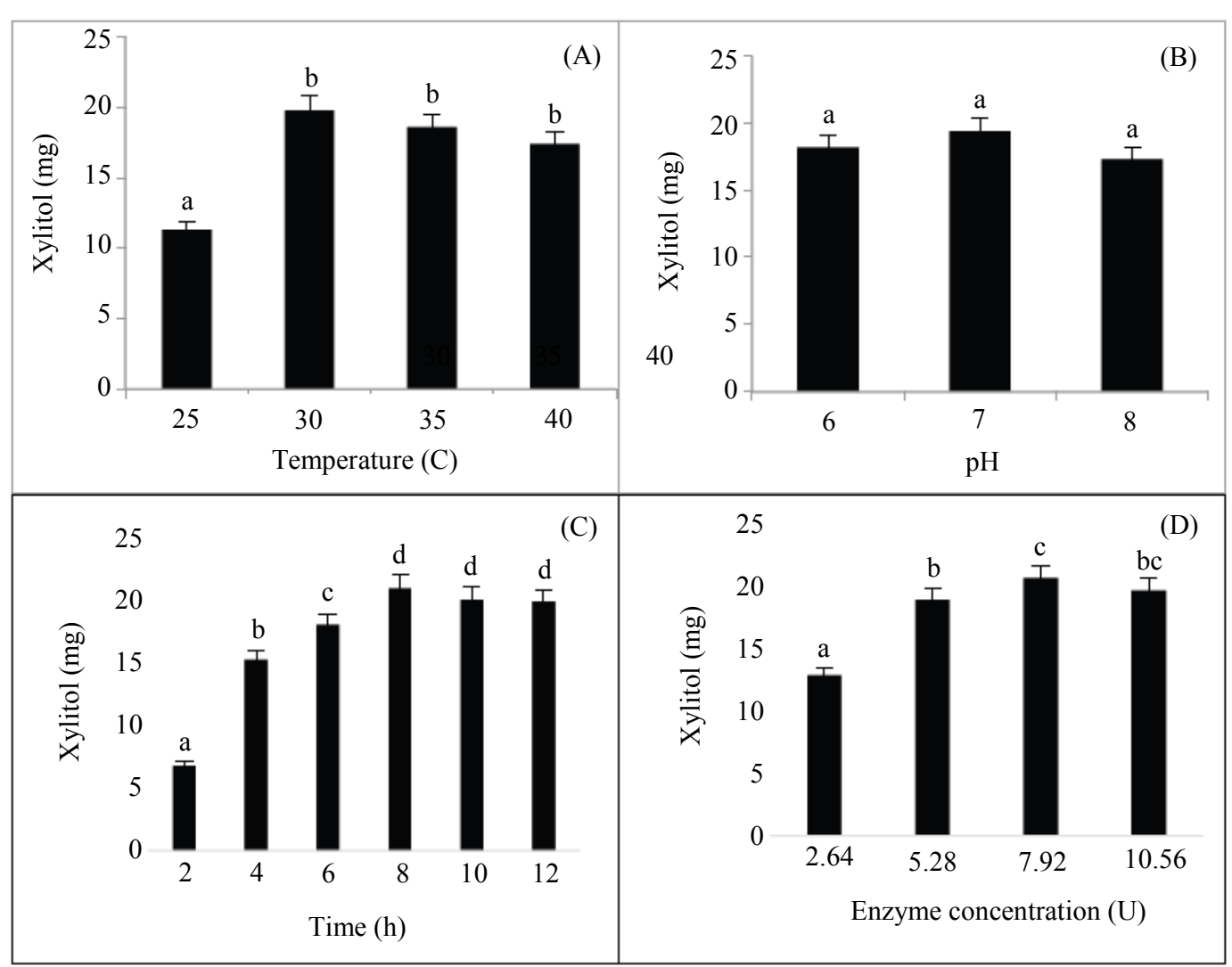

Fig. 1: Effect of conditions on xylitol production from xylose using Crude Xylose Reductase (CXR). All experiments were conducted in $0.1 \mathrm{M}$ phosphate buffer containing a total of $23.59 \mathrm{mg}$ xylose and $10 \mathrm{mM}$ NADPH. A. Effect of temperature at $\mathrm{pH} 7$ for $8 \mathrm{hrs}$ with $7.92 \mathrm{U}$ of CXR. B. Effect of $\mathrm{pH}$ for $8 \mathrm{hrs}$ at $30^{\circ} \mathrm{C}$ with $7.92 \mathrm{U}$ of CXR. C. Effect of time at $\mathrm{pH} 7$ at $30^{\circ} \mathrm{C}$ with $7.92 \mathrm{U}$ of CXR. D. Effect of enzyme concentration at $\mathrm{pH} 7$ for $8 \mathrm{hrs}$ at $30^{\circ} \mathrm{C}$. Error bars indicate standard deviation and values with no common letter within each graph are significantly different at $\mathrm{p}<0.05$

A reaction time of $8 \mathrm{~h}$ resulted in the highest xylitol yield $(86.9 \%)$ and this yield was the same with reaction times up to $12 \mathrm{~h}$ (Fig. 1C). An enzyme concentration of $7.92 \mathrm{U}$ resulted in the highest xylitol yield of $86.64 \%$ and using a higher enzyme concentration did not result in higher yields (Fig. 1D). Overall, the highest xylitol yields were obtained at $30^{\circ} \mathrm{C}, \mathrm{pH} 7,8 \mathrm{hrs}$ with $7.92 \mathrm{U}$ of CXR.

Others have also used a crude enzyme preparation from Candida guillermondii to synthesize xylitol. Branco et al. (2011) used a reverse micelle technique to partially purify XR and synthesized xylitol from xylose at $25^{\circ} \mathrm{C}$ at $\mathrm{pH}$ 7. Cortez et al. (2006) also used the reverse micelle technique to partially purify XR from Candida guillermondii. They showed that the enzyme had an optimum $\mathrm{pH}$ at 6.0 and a high activity range from pH 5.6 to 6.5 which is similar to what we show here. They also showed that the XR was active between $25^{\circ} \mathrm{C}$ and $65^{\circ} \mathrm{C}$ and the highest activity was observed at $65^{\circ} \mathrm{C}$. Here we showed a decrease in enzyme activity at $40^{\circ} \mathrm{C}$ compared to temperatures of $30^{\circ} \mathrm{C}$ to $35^{\circ} \mathrm{C}$. Cortez et al. (2006) did see differences in the XR after reverse micelle purification, presumable due to the effects of the organic solvents (isooctane and hexanol) used in the reverse micelle procedure.

\section{Conclusion}

The enzymatic synthesis of xylitol from wheat straw is feasible. This study showed that a commercial xylanase was able to hydrolyze xylose from wheat straw. Pre-treating the wheat straw via autoclaving resulted in a $22 \%$ increase in reducing sugars with xylanase compared to non-autoclaved wheat straw. This pre-treatment presumably resulted in hydration and swelling of the hemicellulose allowing the xylanase more contact with the substrate. Hydrolysis of pre-treated wheat straw at $50^{\circ} \mathrm{C}$ for $3 \mathrm{~h}$ with $24.8 \mathrm{U}$ of xylanase at $\mathrm{pH} 4.5$ resulted in the highest yield of xylose (9.8\% of total xylose). Additional research on the use of a hydrothermal treatment prior to xylanase hydrolysis may increase the xylose yield. The xylose hydrolysis did need to be adjusted to pH 7 prior to xylitol synthesis with CXR, but the hydrolysate did not need to be detoxified as is necessary with acid hydrolysed biomass for xylitol production via microbial fermentation. The optimal conditions for the 
synthesis of xylitol using the CXR was $30^{\circ} \mathrm{C}$ at $\mathrm{pH} 7$ for $8 \mathrm{~h}$ with $7.92 \mathrm{U}$ of XR and $10 \mathrm{mM}$ NADPH with $23.9 \mathrm{~g}$ xylose. As others have shown, using a dual enzyme system that involves regeneration of the cofactor may be a more economical approach.

\section{Acknowledgement}

This project was partially supported by the Utah State University Utah Agricultural Experiment Station and approved as journal paper number 9067 .

\section{Author Contributions}

Marie K. Walsh: Analyzed data. Interpreted data and wrote the manuscript.

Hussein Fadhil Khliaf: Conducted bench research to generate the data and did some statistical analysis.

Khalida A. Shakir: Had the initial project idea and oversaw the research progress and contributed to the experimental design.

\section{Ethics}

The authors confirm that this manuscript is an original work and the authors have no conflict of interest.

\section{References}

Akpinar, O., K. Erdogan and S. Bostanci, 2009. Enzymatic production of xylooligosaccharide from selected agricultural wastes. Food Bioproducts Process., 87: 145-151.

DOI: $10.1016 /$ j.fbp.2008.09.002

Bajpai, P., 2016. Structure of Lignocellulosic Biomass. In: Pretreatment of Lignocellulosic Biomass for Biofuel Production, Pratima, B. (Ed.), Springer, ISBN-10: 978-981-10-0687-6, pp: 7-12.

Bhalla, A., K.M. Bischoff and R.K. Sani, 2015. Highly thermostable xylanase production from a thermophilic Geobacillus sp. Strain WSUCF1 utilizing lignocellulosic biomass. Front Bioeng. Biotechnol., 3: 1-8. DOI: 10.3389/fbioe.2015.00084

Branco, R.F., J.C. Santos and S.S. Silva, 2011. A solid and robust model for xylitol enzymatic production optimization. J. Bioprocess. Biotechniques, 1: 1-6. DOI: $10.4172 / 2155-9821.1000108$

Cortez, E.V., A. Pessoa-Jr, M.D.G. de Almeida Felipe, I.C. Roberto and M. Vitolo, 2006. Characterization of xylose reductase extracted by CTAB-reversed micelles from Candida guilliermondii homogenate. Brazilian J. Pharmaceutical Sci., 42: 251-257. DOI: $10.1590 / \mathrm{S} 1516-93322006000200010$

de Albuquerque, T.L., I.J. da Silvan Jr., G.R. de Macedo and M.V.P. Rocha, 2014. Biotechnological production of xylitol from lignocellulosic wastes: A review. Process Biochem., 49: 1779-1789.

DOI: $10.1016 /$ j.procbio.2014.07.010
Driss, D., S. Zouari-Ellouzi, F. Chaari, F. Kallel and I. Ghazala et al., 2014. Production and in vitro evaluation of xylooligosaccharides generated from corncobs using immobilized Penicillium occitanis xylanase. J. Mol. Catalysis B: Enzymatic, 102: 146-153. DOI: 10.1016/j.molcatb.2014.02.004

Gibson, T.S. and B.V. McCleary, 1987. A simple procedure for the large-scale purification of $\beta$-Dxylanase from Trichoderma viride. Carbohydrate Polymers, 7: 225-240.

DOI: $10.1016 / 0144-8617(87) 90047-6$

Harper, S.H.T. and J.M. Lynch, 1981. The chemical components and decomposition of wheat straw leaves, internodes and nodes. J. Sci. Food Agric., 32: 1057-1062. DOI: 10.1002/jsfa.2740321103

Jacobs, R.S., 1999. The papermaking properties of Washington State wheat straw. PhD Thesis of Philosophy, University of Washington, Seattle, Washington.

Liavoga, A.B., Y. Bian and P.A. Seib, 2007. Release of D-xylose from wheat straw by acid and xylanase hydrolysis and purification of xylitol. J. Agric. Food Chem., 55: 7758-7766. DOI: 10.1021/jf070862k

Madadi, M., Y. Tu and A. Abbas, 2017. Recent status on enzymatic saccharification of lignocellulosic biomass for bioethanol production. Electronic J. Biol., 12: 135-143.

Miller, G.L., 1959. Use of dinitrosalicylic acid reagent for determination of reducing sugar. Analytical Chem., 31: 426-428.

Mohamad, N.L., S.M.M. Kamal and M.N. Mokhtar, 2015. Xylitol bioproduction: A review of recent studies. Food Rev. Int., 31: 74-89.

DOI: $10.1080 / 87559129 / 2014 / 961077$

Neuhauser, W., M. Steininger, D. Haltrich, K.D. Kulbe and B. Nidetzky, 1998. A pH-controlled fed-batch process can overcome inhibition by formate in NADH-dependent enzymatic reductions using formate dehydrogenase-catalyzed coenzyme regeneration. Biotechnol. Bioeng., 60: 277-282. DOI: $\quad 10.1002 /($ SICI)10970290(19981105)60:3<277::AID-BIT2>3.0.CO;2-E

Rafiqul, I.S.M. and A.M.M. Sakinah, 2013. Processes for the production of xylitol-A review. Food Rev. Int., 29: 127-156.

DOI: $10.1080 / 87559129.2012 .714434$

Rafiqul, I.S.M., A.M.M. Sakinah and A.W. Zularisam, 2015. Enzymatic production of bioxylitol from sawdust hydrolysate: Screening of process parameters. Applied Biochem. Biotechnol. 176: 1071-1083. DOI: 10.1007/s12010-015-1630-2

Sung-Hwan, J., H.Y. Kang, G.J. Kim, J.H. Seo and Y.W. Ryu, 2003. Complete in vitro conversion of Dxylose to xylitol by coupling xylose reductase and formate dehydrogenase. J. Microbiol. Biotechnol., 13: 501-508. 
Steel, R.G.D., J.H. Torrie and D.A. Dickey, 1997. Principles and Procedures of Statistics: A Biometrical Approach. 3rd Edn., McGrawHill Book Co., New York, ISBN-10: 0070610282, pp: 666.

Tamburini, E., S. Costa, M.G. Marchetti and P. Pedrini, 2015. Optimized production of xylitol from xylose using a hyper-acidophilic Candida tropicalis. Biomolecules, 5: 1979-1989. DOI: $10.3390 /$ biom5031979

Walia, A., S. Guleria, P. Mehta, A. Chauhan and J. Parkash, 2017. Microbial xylanases and their industrial application in pulp and paper biobleaching: A review. 3 Biotech., 7: 1-12. DOI: $10.1007 / \mathrm{s} 13205-016-0584-6$

Wan Azelee, N.I. and J.M. Jahim, 2016. Enzymatic hydrolysis of pretreated Kenaf using a recombinant xylanase: Effects of reaction conditions for optimum hemicellulose hydrolysis. Am. J. Agric. Biol. Sci., 11: 54-66. DOI: 10.3844/ajabssp.2016.54.66
Yoon, K.Y., E.E. Woodams and Y.D. Hang, 2006. Enzymatic production of pentoses from the hemicellulose fraction of corn residues. LWT- Food Sci. Technol., 39: 388-392.

DOI: $10.1016 /$ j.lwt.2005.02.005

Zhang, Y., F. Gao, S.P. Zhang, Z.G. Su and G.H. Ma et al., 2011. Simultaneous production of 1,3dihydroacetone and xylitol from glycerol and xylose using a nanoparticle-supported multi445 enzyme system with in situ cofactor regeneration. Bioresource Technol., 102: 1837-1843.

DOI: 10.1016/j.biortech.2010.09.069

\section{Abbreviations}

Xylose Reductase (XR); Crude Xylose Reductase (CXR); Xylanase (XY) 